\title{
Ecology of tropical hermit crabs at Quirimba Island, Mozambique: a novel and locally important food source
}

\author{
David K. A. Barnes* \\ Department of Zoology and Animal Ecology, University College Cork, Lee Maltings, Cork, Ireland“* \\ and \\ Frontier, The Society for Environmental Exploration, 77 Leonard Street, London EC2A 4QS, United Kingdom
}

\begin{abstract}
The semi-terrestrial hermit crabs Coenobita cavipes and Coenobita rugosus are both highly abundant in the supra-littoral zone of Quirimba Island, northern Mozambique. In the open sand scrub environment the principal food sources were mangrove propagules and algae for $C$. cavipes and rotting terrestrial vegetation for $C$. rugosus. Increased use of the mangrove habitats on Quirimba Island by the local human population has resulted in human faeces as a potential source of food for hermit crabs. The level of use of this resource differs between the 2 species and between habitats, but not significantly between day and night. Both species exhibited gregarious behaviour on food items, particularly $C$. cavipes on human faeces (up to 61 individuals on 1 food item). Both species exhibited cannibalism during the study period, but this constituted less than $1 \%$ of their diet. The foraging distances of both species increased with individual size and differed with habitat in C. cavipes.
\end{abstract}

KEY WORDS: Hermit crab Forage distance Faeces - Africa Gregarious · Cannibalism

Most mangrove dwelling or associated decapod crustaceans tend to be deposit feeders on either leaf litter (e.g Sesarma) or sedimentary organic matter (e.g. Uca). Hermit crabs, particularly those of a semiterrestrial nature (coenobitids), are described in the literature as feeding generalists and scavengers with a wide dietary intake. The diets of tropical species have generally been found to centre on fruit, with rotting vegetation, dead fish and bird droppings also being eaten (Burggren \& McMahon 1988). Although cannibalism has been recorded for many terrestrial crabs, coenobitids have been noted as fairly tolerant and may feed gregariously on larger food windfalls (De Wilde

\footnotetext{
-E-mail: dkab@ucc.ie

*Address for correspondence
}

1973). Hermit crabs may have to compete strongly with other animals for such food items, often resulting in procurement of low quality food (Vannini 1976).

The Quirimba Archipelago in northern Mozambique, East Africa, has a wide diversity of intertidal zone decapod crustaceans, hermit crabs in particular (Barnes 1997a). Coenobita cavipes and Coenobita rugosus are both highly abundant in the supra-littoral zone of Quirimba Island. They occur in a range of habitats and show unusual behavioural patterns such as tree climbing (Barnes 1997b). The growing local human population on Quirimba Island uses the mangrove swamps for collection of food, fuel, building materials and for defecation (Frontier unpubl. data). The former of these uses has potential influences on the hermit crab population indirectly through the deposition of empty shells within the supra-littoral zone and the removal of predators. This study focuses on the influence of the latter of the human population uses, defecation, as a food source.

Methods and results. Observations were made on the feeding behaviour and nature of food items of tropical hermit crabs at Quirimba Island (for map see Barnes 1997a) during August 1996. Three upper-shore/ supra-littoral zone species of hermit crab occurred within the study area, Clibanarius longitarsus, Coenobita cavipes and Coenobita rugosus. C. longitarsus is very different in appearance to the Coenobita species, which are separated by the markings on the chela of $C$. rugosus. $C$. longitarsus was only observed to feed at high water and not considered in this study. The 2 coenobitid species were studied in each of the 3 major habitats in which they occur at Quirimba Island, dense mangrove, fringe mangrove and open sand scrub areas. Observations were made in $4 \mathrm{~m}^{2}$ plots during day low water and night low water in the dense mangrove and fringe mangrove habitats but just night low 
water in the open sand scrub habitat. Neither of the coenobitid species have been found to actively feed between 07:00 and 17:00 $\mathrm{h}$ in the open sand scrub habitat at this location (Barnes 1997a). The food items available and used in the supra-littoral zone were grouped into 6 categories: (1) mangrove propagules; (2) algae (shredded macro-algae on drift line); (3) decomposing terrestrial plant material; (4) dead or injured Coenobita species (cannibalism. i (5) dead or injured fauna; (6) human faeces. The mean foraging distances of $C$ cavipes and C. rugosus were measured by recording the positions of individuals at 30 min intervals. The positions were categorised into the 3 habitats and the crabs into $<1,1-5$ and $>5 \mathrm{~g}$ size classes.
The proportions of each food item used by Coenobita cavipes and C. rugosus individuals are shown for the 3 habitats in Tables 1, 2 \& 3. The most important food items in the open sand scrub environment were mangrove propagules and algae for $C$. cavipes and rotting terrestrial vegetation for C. rugosus. By contrast, in the fringe mangrove habitat, human faeces was found to be significantly the most important day and night food source for $C$. cavipes (ANOVA, $p<0.05$ for both). Mean numbers of $C$. rugosus in the fringe mangrove habitat wero highest on rotting terrestrial vegetation. Human faeces was, however, not used significantly less than rotting terrestrial vegetation at this habitat even by day (ANOVA, $F=1.6, p=0.36$ ). The overall

Table 1. Numbers of food items used by Quirimba Island coenobitid hermit crabs in the open sand scrub habitat. Data are means and stanctard deviations are given in parentheses, $\mathrm{N}=$ no. of crabs observed

\begin{tabular}{|c|c|c|c|c|}
\hline \multirow{2}{*}{ Food item } & \multicolumn{2}{|c|}{ Coenobita cavipes } & \multicolumn{2}{|c|}{ Coenobita rugosus } \\
\hline & $\begin{array}{c}\operatorname{Day}^{d}(09: 00 \mathrm{~h}) \\
N=0\end{array}$ & $\begin{array}{c}\text { Night (21:00 h) } \\
N=138\end{array}$ & $\begin{array}{c}\operatorname{Day}^{4}(09: 00 \mathrm{~h}) \\
N=0\end{array}$ & $\begin{array}{c}\text { Night }(21: 00 \mathrm{~h} \\
\mathrm{N}=206\end{array}$ \\
\hline Mangrove propagules & 0 & $3.0(0.8)$ & 0 & $1.1(0.8)$ \\
\hline Algae & 0 & $3.5(1.5)$ & 0 & $3.1(1.2)$ \\
\hline Decomposing plants & 0 & $0.9(0.8)$ & 0 & $7.8(2.9)$ \\
\hline Cannibalism & 0 & 0 & 0 & $0.1(0.4)$ \\
\hline Dead/injured fauna & 0 & $1.3(1.2)$ & 0 & $0.8(0.8)$ \\
\hline Human excreta" & 0 & 0 & 0 & 0 \\
\hline
\end{tabular}

Table 2. Numbers of food items used by Quirimba Island coenobitid hermit crabs in the fringe mangrove habitat. Data are means and standard deviations are given in parentheses

\begin{tabular}{|c|c|c|c|c|}
\hline \multirow[t]{2}{*}{ Food item } & \multicolumn{2}{|c|}{ Counobita cavipes } & \multicolumn{2}{|c|}{ Coenobita rugosus } \\
\hline & $\begin{array}{c}\text { Day }(09: 00 \mathrm{~h}) \\
\mathrm{N}=277\end{array}$ & $\begin{array}{c}\text { Night (21:00 h) } \\
\quad \mathrm{N}=240\end{array}$ & $\begin{array}{c}\text { Day }(09: 00 h) \\
\quad N=105\end{array}$ & $\begin{array}{c}\text { Night }(21: 00 \mathrm{~h}) \\
N=113\end{array}$ \\
\hline Mangrove propagules & $3.1(0.8)$ & $2.0(0.8)$ & $1.8(0.7)$ & $2.2(0.5)$ \\
\hline Algae & $3.5(0.9)$ & $2.8(0.7)$ & $3.3(0.9)$ & $3.2(0.7)$ \\
\hline Decomposing plants & $0.9(0.8)$ & $1.3(0.9)$ & $4.9(1.2)$ & $5.9(1.6)$ \\
\hline Cannibalism & $0.1(0.4)$ & 0 & 0 & 0 \\
\hline Dead/injured fauna & $1.4(1.4)$ & $0.6(0.9)$ & $1.0(0.9)$ & $0.6(0.7)$ \\
\hline Human excreta & $21.0(7.0)$ & $18.3(6.1)$ & $3.3(1.2)$ & $5.1(1.5)$ \\
\hline
\end{tabular}

Table 3. Numbers of food items used by Quirmba Island coenobind hermit crabs in the dense mangrove habitat. Data are means and standard deviations are given in parentheses

\begin{tabular}{|c|c|c|c|c|}
\hline \multirow[t]{2}{*}{ Food item } & \multicolumn{2}{|c|}{ Coenobita cavipes } & \multicolumn{2}{|c|}{ Coenobita rugosus } \\
\hline & $\begin{array}{c}\text { Day }(09: 00 \mathrm{~h}) \\
\quad N=220\end{array}$ & $\begin{array}{c}\text { Night }(21: 00 \mathrm{~h}) \\
\mathrm{N}=218\end{array}$ & $\begin{array}{c}\text { Day }(09: 00 \mathrm{~h}) \\
N=0\end{array}$ & $\begin{array}{c}\text { Night }(21: 00 \text { h) } \\
\quad N=0\end{array}$ \\
\hline Mangrove propagules & $2.4(0.9)$ & $2.8(0.7)$ & 0 & 0 \\
\hline Algae & $1.6(0.7)$ & $1.5(0.5)$ & 0 & 0 \\
\hline Decomposing plants & $1.1(1.4)$ & $1.1(0.4)$ & 0 & 0 \\
\hline Cannibalism & $0.3(0.5)$ & 0 & 0 & 0 \\
\hline Dead/injured fauna & $1.3(1.6)$ & $1.3(1.5)$ & 0 & 0 \\
\hline Human excreta & $48.1(6.0)$ & $44.2(6.3)$ & 0 & 0 \\
\hline
\end{tabular}


Table 4. Foraging distance $(\mathrm{m})$ travelled in the 3 habutats by the 3 size classes of coenobitid hermit crabs whthin 1 low tide period $(6 \mathrm{~h})$. Data are means and standard deviations are given in parentheses, $n=10$ individuals for each mean

\begin{tabular}{|c|c|c|c|c|c|}
\hline \multirow{2}{*}{$\begin{array}{l}\text { Size class } \\
\text { (g) }\end{array}$} & \multicolumn{3}{|c|}{ Coenobita cavipes } & \multicolumn{2}{|c|}{ Coenobita rugosus } \\
\hline & Mangrove & Fringe & $\begin{array}{l}\text { Open sand } \\
\text { scrub }\end{array}$ & Fringe & $\begin{array}{l}\text { Open sand } \\
\text { scrub }\end{array}$ \\
\hline$<1$ & $1.9(0.8)$ & $1.7(1.0)$ & $-{ }^{a}$ & $2.8(1.3\}$ & $3.2(1.1)$ \\
\hline $1.5-5$ & $3.6(1.5)$ & $4.6(2.4)$ & $6.0^{11}$ & $6.2(3.0\})$ & $7.7(3.5)$ \\
\hline$>5$ & $5.7\{2.6\}$ & $10.8(6.7)$ & $18.6(7.3)$ & $8.2(3.1)$ & $10.3(5.6)$ \\
\hline
\end{tabular}

an order of magnitude. To C. rugosus, in contrast, the impact of this novel food source (in geological time) is relatively minor and is only used at the same level as several other food sources. The importance of human faeces as a food source increases from fringe to dense mangrove habitats; however, faeces are not available in the open sand scrub habitat. The proportional level of use of this food item (or any other food item) did not significantly change with day or night

decrease in feeding from day to night in C. cavipes and from night to day in $C$. rugosus was significant in neither case (ANOVA, $p>0.05$ for both). As for in the fringe mangrove habitat, in the dense mangrove habitat human faeces was found to be by far the most important food source for $C$. cavipes. In the dense mangrove habitat the proportion of individuals utilising this food source was significantly higher than in the fringe mangrove habitat (ANOVA, $F=75.1, \mathrm{p}<0.01$ ). The density of faeces was not, however, different between these sites (ANOVA, $F=1.07, \mathrm{p}=0.32$ ). Gregarious behaviour was also higher around human faeces than other individual food items. The largest number of hermit crab individuals recorded at a single item of excreta was 61 ( $C$. cavipes) compared to a maximum of just 5 ( $C$. cavipes) at any other food source. Cannibalism occurred in all 3 habitats and for both $C$. cavipes and $C$. rugosus, although more frequently for the former species.

The mean foraging distances travelled by Coenobita cavipes and $C$. rugosus individuals are shown for the 3 habitats and 3 size classes in Table 4 . Foraging distance increased with individual size in all cases (ANOVA, all $p<0.05$ ) and differed between habitats. The $C$. cavipes in the open sand scrub habitat foraged significantly further (ANOVA, $F=7.3, p<0.05$ ) than those in the fringe mangrove, which in turn travelled further than those in the dense mangrove (ANOVA, $F=5.09, p<0.05)$. Although the data suggest that C. rugosus in the open sand scrub habitat travelled further than those in the fringe mangrove habitat, this was statistically insignificant. The differences between the 2 species was also insignificant.

Discussion. The feeding preferences of the supralittoral zone hermit crabs Coenobita cavipes and $C$. rugosus overlap substantially but differ in the proportions of different food sources used. The use of the mangrove habitats by a growing local human population (Frontier unpubl. data) has created a novel food source, human faeces, which is utilised by both species. During the study period human faeces was the most utilised food source of $C$. cavipes by more than feeding. The provision of this resource in addition to empty shell piles, as well as the removal of predators (Barnes unpubl. data), means the human population may have a substantial influence on Quirimba Island coenobitid hermit crabs. Vannini (1976) describes East African coenobitids as generally recipients of low grade food through competition for resources. The quality of human faeces as a source of assimilable organics for hermit crabs is unknown, but probably relatively high compared to rotting vegetation. Observations suggested that individuals passing within about $5 \mathrm{~m}$ of a gathering of hermit crabs utilising this food source, at day or night, would alter course and join the aggregation. Their mechanism of prey detection is unknown, but the similar species Coenobita compressus has been described as using chemoreception over short distances and sight over longer range (Kurta 1982).

That foraging distances change with individual size and habitat is unsurprising due to differences in mobility and food distribution respectively. Both species undertake sub-daily vertical migrations at Quirimba Island (Barnes 1997b) and Coenobita rugosus has been described as making large seasonal migrations in Somalia (Vannini 1976). The data suggest but do not confirm that there may be differences between the 2 species in terms of foraging ranges. This would explain the greater proportion of time spent walking (compared to feeding) by C. rugosus (Barnes 1997 a). Subtle differences in dietary and habitat preferences and foraging ranges may be important in resource partitioning, allowing these 2 similar species extensive overlap in distribution and activity.

Acknowledgements. The author thanks all the scientific staff, logistic staff and volunteer research assistants of the Darwin/Frontier Mozambique Marine Research Programme. This is a collaborative venture between the Society for Environmental Exploration (SEE) in the U.K. and the Ministepara a Coordenaçào de Acçào Ambiental (MICOA) in Mozambique and is part funded by the Darwin Initiative for the Survival of Species (Department of the Environment, U.K.). I am also very grateful to Damon Stanwell-Smith for being instrumental in the travel to Mozambique. 


\section{LITERATURE CITED}

Barnes DKA (1997a) Ecology of tropical hermit crabs at QuirImba Island, Mozambique: distribution, abundance and activity. Mar Ecol Prog Ser 154:133-142

Barnes DKA (1997b) Ecology of tropical hermit crabs at Quirimba Island, Mozambique: vertical migration (tree climbing). Mar Ecol Prog Ser 158:233-240

Burggren WW, McMahon BR (1988) Biology of the land crabs. Cambridge University Press, Cambridge

Editorial responsibility: Otto Kinne (Editor),

Oldendorf/Luhe, Germany
De Wilde PAWJ (1973) On the ecology of Coenobita clypeatus in Curaçao with reference to reproduction, water economy and osmoregulation in terrestrial hermit crabs. Stud Fauna Curaçao Other Carib Is! 44:1-138

Kurta A (1982) Social facilitation of foraging behaviour by the hermit crab, Coenobita compressus, in Costa Rica. Biotropica 14:132-136

Vannini M (1976) Field observations on the periodical transdunal migrations of the hermit crab, Coenobita rugosus Milne Edwards. Monit Zool Ital 7:145-195

Submitted: September 22, 1997; Accepted: December 1, 1997 Proofs received from author(s): December 22, 1997 